\title{
THE PRESENT AND FUTURE OF ALTERNATIVE WASTE TREATMENT APPROACHES IN THE UNITED STATES: TONNAGE AND TRENDS
}

\section{Eileen Brettler Berenyi *}

Principal, Governmental Advisory Associates Inc., 599 Riverside Ave. Westport Connecticut, USA

Research Associate, Waste-to Energy Research and Technology Council, Fu School of Engineering and Applied Sciences, Columbia University, New York, USA

Article Info:
Received:
30 January 2018
Revised:
12 July 2018
Accepted:
29 August 2018
Available online:
30 September 2018
Keywords:
U.S. environmental policy
Energy from waste
Recycling processing
U.S. waste industry

Article Info:

Received:

Revised:

12 July 2018

30 September 2018

Keywords:

Energy from waste

U.S. waste industry

\begin{abstract}
Based on a series of surveys conducted by the author and her firm over the past twenty-five years, the paper documents trends in alternative pre-disposal municipal waste treatment approaches in the United States, namely curbside recycling and energy from waste initiatives. Recycling tonnage and the corresponding percentage of the waste stream recycled has increased steadily since the 1990s, but has appeared to reach a plateau of about $28 \%$ currently. If one adds organics composting to the tonnage, the percentage rises to about $34 \%$. While recycling of inorganic materials has encountered economic headwinds, curbside organics recycling programs appear to be increasing, leading to a rise in aerobic or anaerobic treatment programs in the future. Oppositely, conventional energy from waste initiatives have stalled in the United States. With the exception of one recently opened facility, no new plants have been built, although several have or are undergoing expansion. About $13 \%$ of the municipal waste stream is currently being processed at energy from waste plants. Within the next five years, this percentage could drop to about $10 \%$, with numerous facility closings anticipated. In the future, it appears that the municipal waste stream in the United States will become increasingly disaggregated, resulting in a number of small to mid-sized processing plants handling these various streams. Nearly $50 \%$ of the waste stream will continue to be landfilled.
\end{abstract}

\section{INTRODUCTION}

The purpose of this paper is to examine trends in the pre-disposal treatment of waste in the United States, specifically as it relates to recycling, energy from waste, and the possible convergence of the two into an integrated strategy of the future. Drawing on a series of surveys conducted by the author, it will assess the direction of recycling and waste to energy in the United States. As of 2017, both national and international trends are impacting waste management in the United States. With adequate land available for landfilling waste in many regions of the country, the comparatively low price of landfilling, coupled with the low cost of energy and a volatile commodities market, there is little incentive for most localities to invest in capital intensive waste disposal alternatives. With the United States' decision to withdraw from the Paris Climate Accords, and the Trump Administration's lack of serious commitment to the mitigation of greenhouse gas emissions, there is not likely to be any major national policy initiatives to stimulate innovative waste reduction and energy conservation approaches. In the near future, states and localities will be taking the lead in implementing innovative waste management strategies.

In the United States, the federal government sets overall solid waste management policy, particularly in the regulatory arena, but it is left to states and localities to implement these regulations. There is large variation among states as to the level of commitment to alternative disposal methods. While curbside recycling has become the norm in almost all U.S. communities, most of the remaining waste in the U.S is landfilled. As shown in the latest U.S. Environmental Protection Agency (USEPA) report, $25.7 \%$ of municipal solid waste is recycled, $8.9 \%$ is composted, $12.8 \%$ is combusted with energy recovery, and the remaining $52.6 \%$ is landfilled. In 2000 the corresponding percentages were $23.0 \%$ recycled, $7.1 \%$ composted, $13.8 \%$ combusted with energy recovery and $56 \%$ landfilled. Thus, over the past 15 years, there have been some gains in the percentage of waste recycled and composted, but a decrease in the proportion of waste going to waste to energy. Corresponding- 
Iy, reliance on landfilling has decreased by about 3\% over the fifteen-year period. While the USEPA has promulgated the waste hierarchy of re-use, reduce, recycle, energy recovery, landfilling, there are no national directives compelling states or localities to implement the hierarchy in any particular way.

The remainder of the paper will focus on waste treatment prior to ultimate disposal. It will delve further into the numbers with respect to post consumer recycling and waste to energy. The general finding is that in the United States, recycling rates have reached a plateau due to various challenges confronting the industry. Reliance on energy from waste facilities has been declining in the last five years and will continue to do so over the next five-year period. Existing plants are facing the multiple challenges of age, low energy prices, stable landfill prices and lack of government policies to support the industry through subsidized energy pricing or other programs. Growth in alternative disposal methods will mainly occur in the treatment of food waste and other organics, since a number of localities are implementing source separated organics (food and plant waste) collection and other food waste reduction programs.

A mention should be made of additional energy from waste initiatives occurring on solid waste landfills throughout the United States, by which landfill gas is collected, cleaned and converted to electricity or used directly as a medium BTU fuel directly in boilers or as a high BTU pipeline quality gas. According to the United States Environmental Protection Agency, as of January 2018 there are 632 operational landfill gas recovery projects in the United States, with 40 more either under construction or planned. The majority of these projects generate electricity, 74\%, with $19 \%$ creating a medium BTU gas for direct use and $6 \%$ producing a high BTU pipeline quality gas. A few projects are also generating a synfuel for use in vehicles. In total, these landfills are producing about $2200 \mathrm{MW}$ of electricity. Some federal tax credits were available to assist these projects, but they have expired as of December 2016. Because the paper focuses on waste treatment or diversion prior to landfill, landfill gas to energy, while a highly successful means of generating energy from waste will not be a topic of this discussion going forward.

\section{METHODOLOGY}

The data in the paper is obtained from a series of surveys undertaken by the author and staff through her firm Governmental Advisory Associates Inc. Beginning in the 1980s, Governmental Advisory Associates Inc. conducts periodic surveys of waste to energy and recycling facilities in the United States. A detailed questionnaire has been developed and is periodically administered by telephone to plant operators, public officials, and private firms which own the facilities. The surveys cover technical aspects of the plant, types of equipment, types and quantities of materials processed, as well as the financial and contractual arrangements regarding capital and operating costs, waste input and product sales. In addition, information is garnered from state and local government reports, includ- ing financial audits of facilities, government budgets and annual operating reports.

Annual operating reports from plants, state and local reports, municipal or district council minutes, white papers, budgets, consultant reports have been stored for each plant. Each detailed questionnaire with notes are also stored for observation or review at Governmental Advisory Associates, Inc. Westport Connecticut.

\section{RECYCLING}

\subsection{Changing market forces impacting U.S. recy- cling facilities}

Curbside recycling has become the norm in nearly all metropolitan centers in the United States. Even in rural or semi-rural areas, most citizens have access to recycling drop-off containers or a drop-off center. In the residential sector, single stream curbside collection is the predominant form of collection. Residents place their post-consumer fiber and recyclable metal, glass and plastic in a single receptacle without further sorting. The materials are transported to centralized materials recovery facility (MRF) for processing and distribution to markets. In addition, many localities have extended recycling collection programs to the multi-family, commercial and institutional sectors. While the U.S. has seen the expansion of recycling, it is also experiencing challenges to this system. Single stream recycling has broadened the array of materials accepted in the curbside bin and increased the quantity recycled, but it has also placed technological and financial strains on sorting facilities. Residual rates have increased at the same time that markets are demanding a high level of sorting accuracy and product quality. Attaining quality requirements necessitates investments in capital equipment and labor. However, the end markets for much of the recycled product are volatile and often not robust enough to support processing costs. Thus, plants and local users must find methods to share the economic risks of a recycling program, creating budget stress on local government decision-makers and trimming profit margins of participating private firms.

The changes in the international and national environment over the last decade have had substantial and dramatic impacts on the U.S. recycling industry. The years of the Great Recession (2008-2010) battered the world economy, resulting in depressed commodity prices and lower than average waste and recycling volumes. Other economic forces have also worked to disrupt the recycling industry. The oil market has a direct impact on plastic production cost. When oil prices are high, recycled plastic is an attractive substitute for virgin plastics. As prices fall, virgin plastic surpasses recycled plastic as an input. Oil prices in the United States, while plunging in 2009 , began rising steadily after 2010 through 2014. By 2013 the price of oil had recovered from the recession, trading in the range of $\$ 96$ per barrel only to begin falling again in 2014. By 2016 the price of oil had plunged to $\$ 48$ due to a slowdown in Asian economic growth and demand, a strengthening U.S. dollar, and the increased production of shale oil in North America. As of 2017, prices have remained weak. Reflecting these 
changes, the average revenue for recyclable containers fell from a high of about $\$ 160$ per ton in 2012 to $\$ 66$ per ton in 2015. Weak revenues from plastics acts as a drag on prices for other recyclable containers, pulling down overall recycling revenues, forcing MRF operators and local governments to re-evaluate their recycling programs.

In addition, the Asian markets for recyclables are becoming more discerning and careful about products they are importing. In February 2013, China implemented Operation Green Fence followed by National Sword in 20162017 to ensure that only quality plastics and paper were shipped from U.S. MRFs to be used by Chinese companies. Customs checks have been placed on imported materials, with the major focus on plastics and electronics. Chinese inspectors have been sent to U.S. container ports and large processing facilities to monitor shipments. To meet standards, U. S. sorting facilities have invested in upgraded machinery and quality control measures. Product purity has increased, but sorting costs have also increased. Plastics and paper exports have been affected. There may be additional bans of other materials such as scrap metal, in order to build up the domestic Chinese materials recycling industry, should China fully implement the bans it is exploring.

Furthermore, shifts in consumer habits as well as the evolution of packaging is reconfiguring the recycling stream. The amount of newsprint, once a mainstay of recycling programs has declined sharply, as people move to internet-based news. Many MRFs are no longer baling newsprint and are shipping only mixed paper bales. Oppositely, there is an increasing amount of old corrugated cardboard in the stream as consumers abandon brick-and-mortar stores, relying on internet sites for their purchases. Light weighting of packaging has decreased amounts of tin and aluminum and increased the reliance on plastics of various types. Plastics are more difficult to sort and depending on the variety of plastic grades in the stream, require additional labor or capital or both.

U.S. recycling facilities are becoming increasingly automated, with the widespread adoption of optical sorters, ballistic separators and, in a few instances, robotic sorters. Nevertheless, certain materials, create issues with sensitive machinery. Glass if not properly handled can cause problems on the sort line, as can plastic bags and multi-resin plastic containers. Recycled glass requires a regional or local market. Its relatively low market value and heavy weight make it economically infeasible to ship long distances. The result is that various curbside recycling programs are eliminating glass. Similarly, some programs are prohibiting plastic bags and other types of hard to recycle plastics from the recycling bin. Moisture and other contaminants can impact the fiber sort, leading to increased residuals. The average residual rate for single stream facilities is in the range of 17 to $25 \%$ of total incoming materials.

In response to these challenges, MRF operators are being forced to re-negotiate contracts with their customers or re-write new contracts in order to share market risks. When commodity prices were high, MRF operators were able to pay a premium for incoming recyclables and tolerated a broader range of materials with variations in quality. In the current economic environment, operators are being forced to charge a tipping fee to cover their costs, sharing revenues with customers only if market prices for recyclables go above a certain threshold. Faced with climbing residue rates, some MRFs and localities are deciding to cut back on materials accepted in the curbside program, add additional quality control personnel, and educate residents as to the precise materials which belong in the recycling bin.

In part as a result of these world economic trends as well as developments in the national solid waste sector, the $\mathrm{U}$. S. recycling industry has been experiencing the same consolidation sweeping many industries, from banking and telecommunications to health care. Some MRFs have closed due to poor economics, market saturation, antitrust considerations, or the elimination of service. Others have stopped processing and have been re-configured as transportation centers, where materials are baled and shipped to larger, regional processing plants. Despite these economic hurdles, the industry continues to look to the future. There has been ongoing innovation in sorting technology with improvements in the speed and accuracy of sorting and automated feedback systems to spot and in some instances self-correct problems on the processing lines. Robotic technology has been introduced into MRFs, further automating sorting functions. There is a drive to continue the extension of recycling into the construction, commercial and food waste sector. Source separated food and yard waste collection has been implemented in many localities on the West Coast and is being piloted in various communities across the country. In some instances, a convergence of recycling and waste to energy is taking place as localities are looking to use the organic fraction of the waste stream as feedstock for gasification or other energy producing plants.

\subsection{Status of recycling in the United States}

The move to widespread municipal recycling in the United States coincided with the growth of environmental awareness that began in the 1960s. Citizen activism and concern over polluted rivers, air, land soiled by unregulated landfills "dumps", and the overuse of dangerous pesticides documented by Rachel Carson's seminal work The Silent Spring published in 1962, culminated in the creation of the U.S. Environmental Protection Agency (USEPA) by President Nixon in 1970. It was formed, in part, to implement the National Environmental Policy Act (NEPA), passed in 1969 to establish national environmental goals, conduct research on the extent of various types of pollution and means to curb them, and issue grants to states and localities to curb pollution. From 1970 to 1974 a number of national policies and regulations were put in place to arrest environmental damage and preserve and conserve environmental resources. Through federally mandated solid waste management plans, states began to encourage recycling and energy from waste as a means to reduce waste and conserve resources. Furthermore, the USEPA began a decades long initiative to close sub-standard municipal waste "dumps". Through the 1980s, municipal recycling was focused on five major materials: newsprint, corrugated cardboard, tin cans, aluminum beverage containers, glass food and beverage containers. While there were some 
curbside collection programs, most recycling consisted of public areas where such materials could be dropped off. Non-governmental organizations often conducted newspaper or can collection drives to augment their charitable activities. However, by the 1990s, as the federal and state governments increased their focus on resource conservation and waste diversion from landfills, curbside collection of recyclables became popular and spread throughout the country. Plastics became a prominent part of the recycling bin. Processing facilities began to be built to sort the materials being collected from households and business. Figure 1 shows the number of such materials processing facilities through 2016. The dip in 2016 is due to closures as well as consolidation across the industry.

The northeast region of the United States, which encompasses the New England states of Vermont, New Hampshire, Maine, Massachusetts, Rhode Island and Connecticut, New York, Pennsylvania, New Jersey, Dela- ware was one of the first areas to adopt curbside recycling and construct processing facilities. However, as shown in Figure 2, by the late 1990s, processing facilities and the curbside programs they serviced were distributed relatively evenly over all regions in the United States.

The early curbside programs required residents and businesses to pre-sort their recyclables into various containers. Usually there were separate bins for newspaper, cardboard, tin and aluminum cans, glass, and later plastic. Over the years due to economic pressures and technological innovation, the level of pre-sorting of recyclables decreased and the range of materials accepted for recycling increased. Currently, in most localities, citizens do not have to place each type of material into separate bins. Rather they have adopted single stream collection and processing. Residents place all recyclables, fiber, metal, plastic and glass in a single container. The result has been an increase in recyclable tonnage both per facility and in total across

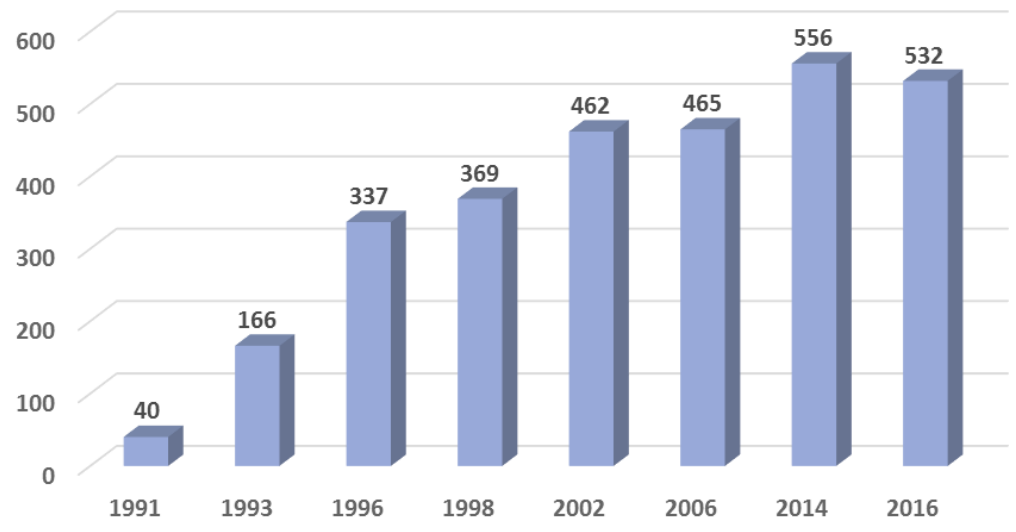

Source: Governmental Advisory Associates Inc. Westport CT

FIGURE 1: Number of materials recovery facilities in the United States.

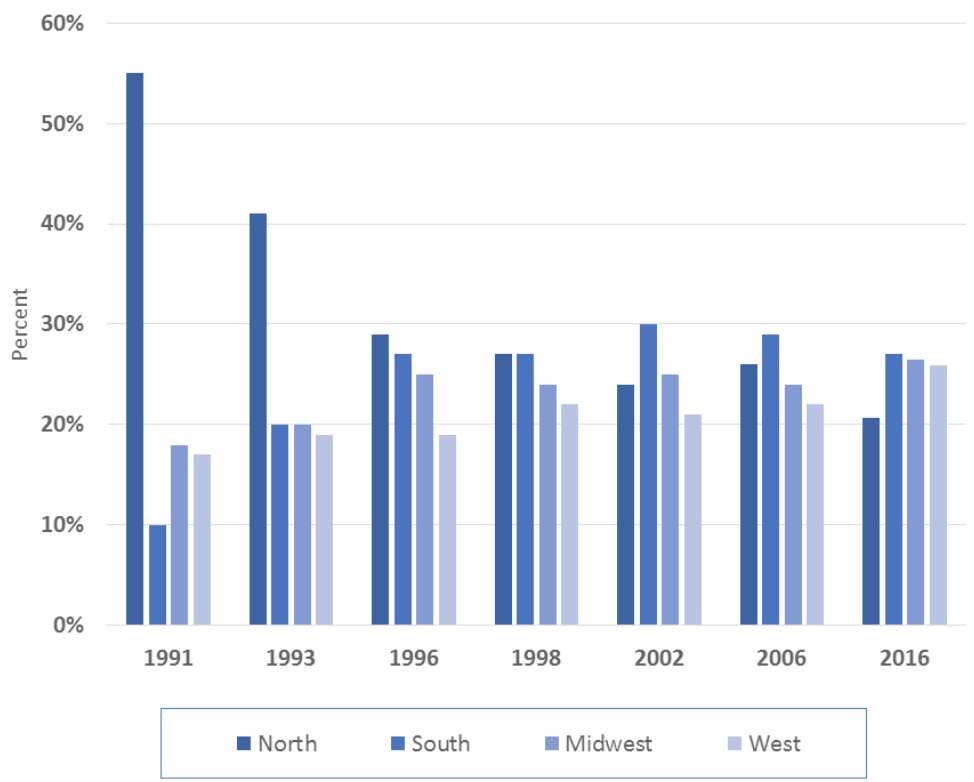

Source: Governmental Advisory Associates Inc. Westport CT

FIGURE 2: Distribution of materials processing facilities by region over time. 
all facilities. Figures 3 and 4 indicate this growth in tons processed per facility as well as total municipal solid waste recycled tonnage processed annually. In $2017,70 \%$ of the multi-material processing facilities in the United State rely on single stream recyclables for their input stream. This compares to $27 \%$ of such facilities a decade ago and $15 \%$ in 2000.

The implementation of single stream collection has forced recycling facilities to invest in upgraded sorting technology to handle the mixed stream. Smaller facilities have been forced out of business as processing plants have become regionalized. The average capital costs to construct a recycling facility have more than doubled from $\$ 6,000,000$ in 2006 to $\$ 15$ million in 2016 . Sophisticated screening technology, intricate digital controls, optical sorters and in a few instances robotic sorters have contributed to the cost. Nevertheless, as mentioned above, material reject percentages have also increased from an average of about $6 \%$ for a facility, where fiber and containers were collected separately to an average of $17 \%-32 \%$ for a single stream sorting plant. Much of the residual percentage is composed of unmarketable glass and mixed plastics.

\subsection{Future recycling trends and tonnage}

According the USEPA, recycling rates in the United States have held relatively steady over the last five years. While the election of President Trump in 2016 has injected an element of uncertainty over the direction of national environmental policy and created some potential state and local budget concerns, several developments indicate that the recycling percentage may increase. Certain states continue to forge ahead with innovative and forceful waste management approaches. California had initially mandated that $50 \%$ of waste must be diverted from landfill, through source reduction, recycling and composting by 2000. In 2012 the state passed AB341 mandating com-

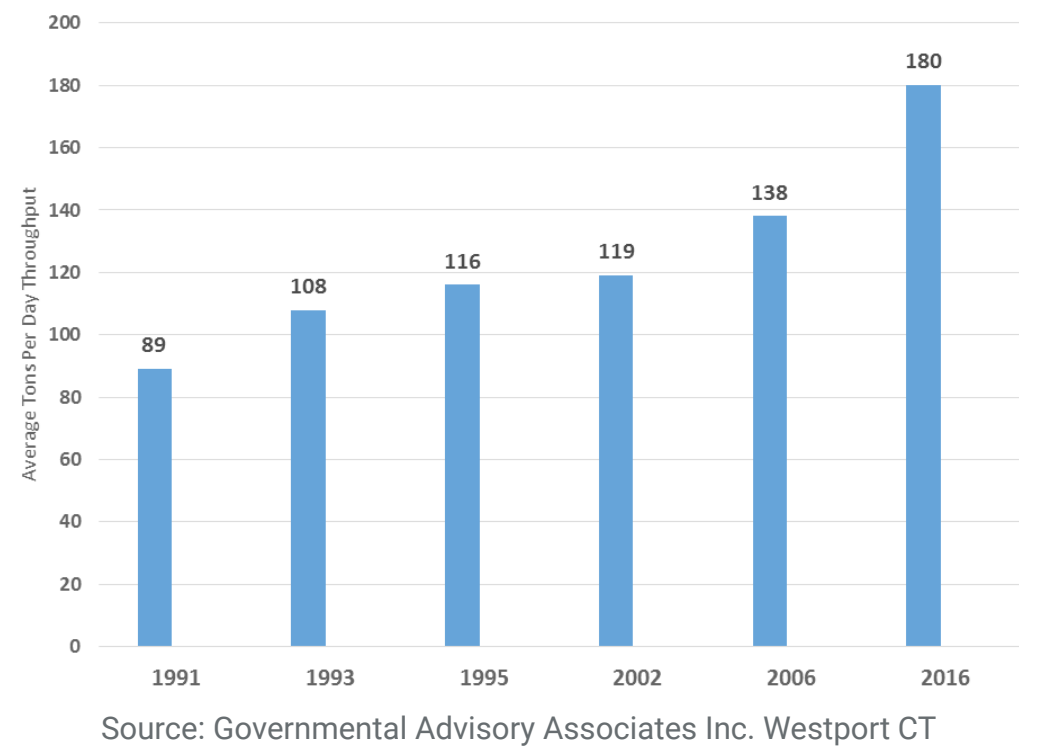

FIGURE 3: Average throughput per processing facility-tons per day.

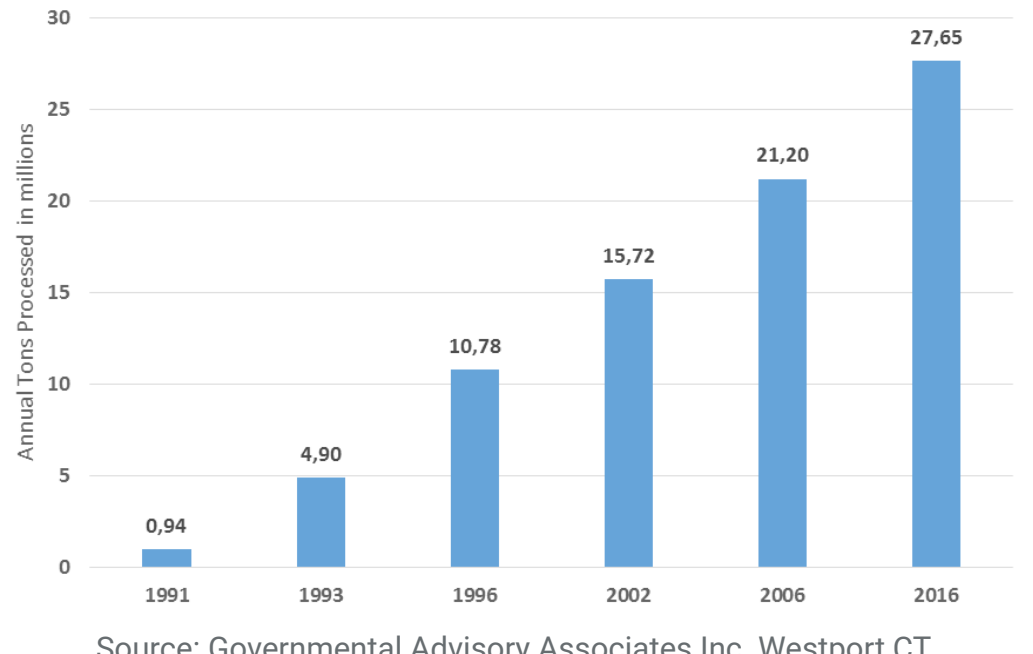

FIGURE 4: Total tons processed annually at materials processing facilities (millions of tons). 
mercial recycling and moving the waste diversion goal to $75 \%$ solid waste diversion by 2020 . Oregon passed a new recycling law in 2015, updating recycling goals for its localities to $52 \%$ by 2020 and $55 \%$ by 2025 . More specifically, it set recovery goals for food and plastic at $25 \%$ by 2020 . In 2012, Vermont enacted Act 148, Universal Recycling and Composting Law, which bans designated recyclables from landfills as of 2015. By 2020 all food scraps generated by residents will be banned from landfills. In 2014 Minnesota expanded its recycling requirements to cover all commercial establishments producing a certain threshold of trash in the seven-county metro area. The recycling goal for the area was increased from 60 to $75 \%$. As of October 2014, Massachusetts has mandated that large food waste generators must separate food waste to be sent to a composting, animal feed, or waste conversion plant. It is imposing a statewide goal of $30 \%$ trash reduction by 2020 . The nation's largest city, New York is implementing separate curbside collection of organic waste and is mandating separate food waste collection from large food generators. As of July 2016, all large-scale food generators must have a separate organics collection. By 2018, all New Yorkers will have separate organics curbside collection or access to a convenient drop off site.

If source separated organics collection continues to be adopted by states and municipalities, U.S. recycling rates would jump substantially. The food waste stream makes up $14.9 \%$ or 38.4 million tons of the 258 million tons of municipal solid waste generated in 2014 . Currently only 1.96 million tons or $5.1 \%$ of total food waste generated is collected for composting or other treatment. If that percentage were increased to $25 \%$ in the next five years, the overall recycling rate would increase to about $41 \%$, landfilling would fall to $49 \%$ of total waste generated, with about 5 million additional food waste tons being diverted from landfill.

A third possible development which may impact recycling in the future is the implementation of mixed waste processing plants. These facilities process a fully mixed solid waste stream, including organics and inorganics. Under this model, citizens no longer do any sorting. All disposal items are thrown into one bin and organics and other recyclables are separated at the plant. There are currently 47 of such facilities, most of which are located in California. Five additional mixed waste plants are being planned in California, handling mainly commercial waste and a few are being planned in the Middle- Atlantic region. In Minnesota, energy-from-waste facilities are planning or have added front end materials sorting capacity, to separate high value materials prior to combustion. With the advance of sorting technologies, including the ability to sort organic from inorganic waste, such plants become technologically feasible. Some of the west coast mixed waste plants are being planned with an adjacent anaerobic digestion facility. The challenges facing these types of plants are mainly economic and institutional. The initial capital costs are high, and revenues from material and energy sales may not cover the operational costs. In fact, a promising plant constructed in Alabama was forced to close after only a few months of operation, due not to technical failure, but economic issues related to lower than planned commodity prices. The
$\$ 30$ million plant, developed by a private firm, was recently purchased by the City of Montgomery for $\$ 625,000$. In addition, even if the economics work, there is opposition to this type of plant from environmental and recycling groups. There is a fear that under this model, citizens no longer will need to pay attention to what they discard, diminishing the concept of waste reduction. After receiving a one million dollar grant from a non-profit organization to examine the feasibility of such a plant, the city of Houston Texas had to abandon the idea. Citizen opposition was such that it did not proceed. Nevertheless, if this type of plant were to be built in parts of the United States with low levels of recycling participation, it might boost recycling tonnage and landfill diversion.

Finally, most relevant to future trends in recycling is the re-imagining of waste stream management that is currently occurring. The USEPA through its Sustainable Materials Management (SMM) Program is moving away from a focus on disposal of unwanted materials to the appropriate handling and marketing of the various material streams that compose the waste stream . Its three strategic priorities are 1) focusing on sustainable building through use of environmentally sensitive materials; 2) developing sustainable food management initiatives through supporting alternatives to the landfill disposal of waste food and encouraging methods to reduce food waste; 3 ) Continuing to support sustainable packaging through improved product design, life cycle analysis. As localities move to different types of collection systems, such as source separated organics collection, they are re-thinking their materials processing infrastructure. Some communities are moving to a two-bin collection system comprised of organics in one bin and inorganics in the other. The organics are sent to an anaerobic digester or composting facility for the production of energy or compost material. The inorganics go to a processing facility, where valuable materials are separated. Residuals may go to landfill or to an energy from waste plant. Other communities are adopting a three-bin system, where organics and soiled paper are placed in one bin, non-contaminated inorganic recyclable materials in a second bin, with the remaining discards placed in the third bin. Should such systems take hold across the country, one could anticipate and major increase in recycling tonnage, energy from waste facilities, as well as a major reduction in waste going to landfill. These types of systems create a natural synergy between recycling and energy from waste.

\section{ENERGY FROM WASTE}

\subsection{Market forces impacting energy from waste in the United States}

The shifts occurring in the re-thinking of waste management approaches are having a distinct impact on energy from waste initiatives in the United States. With the potential disaggregation of the waste stream into component categories, organic, inorganic recyclables, residuals, there is new focus on gasification technologies using the organic or residual stream. As the waste stream becomes more segmented, any new facility may have to be scaled down from those existing energy from waste facilities that are 
combusting a less segmented stream. As of 2014, energy from waste facilities are processing about $12.8 \%$ of municipal waste generated in the United States. This percentage reached a high of $14 \%$ in 2000 and has hovered in the $12 \%$ range since that time. An average energy from waste plant, handling municipal solid waste combusts about 1100 tons per day, producing about 28 megawatts of electricity. The growth of the energy from waste initiative in the United States grew out of the turbulent 1970s, driven in part by the Middle East oil embargo and the birth of the environmental movement. In the midst of soaring oil prices, the federal government began to encourage alternative energy projects, including energy from waste plants. Various financial and tax policies were enacted to stimulate the development of such facilities. Under the 1978 Public Utility Regulatory Policies Act, which sought to promote energy conservation and use of renewable energy, power utilities were required to purchase electricity from qualifying facilities (generating under $80 \mathrm{MW}$ of power) that used waste, biomass, or other renewable fuels. Rates paid to QFs were to be equal to the "avoided cost" to the utility, defined as the incremental energy and capacity cost the utility would have incurred but for the purchase from the qualifying facility. With the high cost of oil during that period of time and fuel shortages projected into the future, waste to energy facilities were able to enter into long term, 20 to 25-year power purchase agreements with utilities at advantageous rates.

Furthermore, during this same period the country was turning its focus to cleaning up the environment and preventing further environmental degradation through air, water, and land pollution. As cited previously, the United States through the newly formed Environmental Protection Agency and its predecessor departments mandated the closure of sub-standard landfills throughout the country. Numerous facilities shut down, driving up landfill costs and forcing state and local officials to look at alternatives. The USEPA assisted in these efforts, providing technical assistance and grants to localities looking to procure waste to energy plants or implement other types of resource and energy conservation programs. Given the favorable regulatory and policy environment through the mid-1980s, states and localities implemented the construction of energy from waste plants. By 1990, 127 of these plants had begun operations with another 63 in the planning stages.

In the 1990s, the U.S. EPA turned its attention from encouraging the development of energy from waste plants to regulating the potential harmful air pollutant effects of such plants. Of particular concern were the carcinogenic effects of dioxins and furans emitted during the combustion process, the toxicity of incinerator ash, and the monitoring and testing of these impacts. By 1995, the U.S EPA had promulgated stringent new air emission standards, requiring energy from waste facilities to install maximum available control technology (MACT) to control for particulate emissions, dioxins, furans, nitrous oxide, sulfur dioxide, heavy metals and other harmful pollutants. These standards are to be revisited every five years. Emissions standards for certain substances continue to be adjusted downward as new control technologies have been developed. These regulations forced many plants to make costly upgrades to their air pollution control and management systems.

Additional policy changes impacting energy from waste initiatives were occurring during this period. A national tax reform package enacted in 1986, eliminated favorable future tax incentives for investment in energy from waste plants. Also, by the 1990s, the energy supply picture had begun to change. The U.S utility industry was substantially de-regulated. New sources of oil were found and utilities turned to alternative fossil fuels such as coal and natural gas. Counter to earlier predictions, energy prices began to fall. Individual state utility commissions charged with setting the avoided cost rates at which energy from waste facilities could sell their electricity moved to a competitive bidding method. Due to decreasing energy prices, as energy from waste facilities renewed their power sales contracts, their electricity revenues fell dramatically. In many cases, energy from waste plants began to sell power on the open market, without the benefit of a long-term, stable, above market power sales agreement.

Just as the price of energy failed to continue its predicted rise, a similar development occurred with solid waste disposal prices. Beginning in the 1970s, and continuing through the 2000s, the number of municipal solid waste landfills dropped from approximately 10,000 to 1900. The modern landfill of today is strictly regulated by federal, state, local governments for leachate control, liner construction and methane gas control. With the decline in landfill numbers, it was expected that the shrinking disposal capacity, would cause landfill disposal prices would rise. Prices did more than double from 1980 through 1995 to $\$ 50.00 /$ ton; however, in the mid-1990s landfill prices began a slow decline, leveling off to about in the $\$ 48-\$ 50 /$ ton range. (2014 dollars). Landfills that met federal standards were able to expand and new large landfills opened. When they were first constructed in the 1980s and 1990s, energy from waste facilities were anticipating stable, subsidized electricity prices and rising waste disposal fees. However, with a largely de-regulated energy and waste disposal market, these energy from waste plants have been forced to keep their disposal fees competitive, placing additional downward pressure on their revenues.

Adding to downward pressure on energy from waste revenues, the Supreme Court of the United States in its decision of C\&A Carbone v. Town of Clarkstown, struck down flow control, the power of a locality to direct all waste generated within its confines to a specific facility. The court held that flow control violated the freedom of interstate commerce, since the plaintiffs were forced to use a waste disposal facility within the town that was more costly than alternative facilities out of state. Energy from waste facilities relied on flow control to ensure that they had an adequate waste flow at set disposal prices. This decision was modified with a later decision that permitted flow control if the disposal facility was publicly owned and operated. However the overall impact of these court rulings was that many energy-from-waste projects were forced to decrease their disposal tip fees, as long term waste delivery contracts between municipalities and plants expired.

With a single exception, all 78 energy from waste plants currently operating in the United States have been built in 
the 1980 s or early 1990 s. Many have been substantially upgraded and can continue to operate into the future, but others are reaching the end of their operational life. Their economic future is further muddied by various long term contractual arrangements that are expiring, both for the sale of their energy product as well as for the incoming waste. Facilities are being forced to compete in the waste disposal market, with inherent limits as to how much they can charge for tip fees. With prevailing landfill rates in the range of $\$ 50.00$ per ton, it is difficult for plants to charge rates above those prevailing in their area. The challenging economic picture is exacerbated by continuing low energy and recycled metal prices. Since very few states are offering electric rate subsidies based on the use of waste as a renewable fuel, plants are confronting declining or flat energy revenues. Furthermore, certain states such as California, New York, New Jersey have placed a moratorium on the construction of new waste to energy plants using combustion or have limited these plants' access to renewable energy credits. While waste generation rates have held steady, the segmentation of waste streams to food waste and recyclables is diverting materials from existing energy from waste plants. Many have excess capacity, which adds to their uncertain economic future.

\subsection{Current status of energy from waste plants in the United States}

Reliance on conventional municipal waste combustion to energy is declining in the United States due to the economic and political challenges cited above. While in a few places plants have expanded, only a single facility in Palm Beach County, Florida has been newly built since 1995. Figure 5 shows the number of facilities in operation and planned by year since 1982. The growth and maturation of the industry can be clearly seen. Through 1988, the number of planned facilities outstripped the number of operating plants, while the number of operating plants also grew steadily. The years 1990 to 1993 were a turn- ing point. The number of operating plants peaked and the number of planned facilities dropped drastically. In 1993 there were 150 operating energy from waste plants in the United States. By 2015, that number had been nearly halved to 78 . Also by 1996, planning for new facilities had essentially stopped. However, as of 2010 , there has been some change in the direction. In conjunction with source separated organics collections, communities have begun to examine the feasibility of anaerobic digestion. A few of these plants are being constructed. In addition, various types of waste gasification or other conversion plants for certain waste streams are being developed. These are largely small pilot projects, depending on a segregated organic or residual plastics waste stream. There are currently no planned conventional waste combustion plants, relying on an unsegregated municipal waste stream.

While numbers of plants have declined, total tonnage processed by energy from waste projects has held steady over the last decade. Many of the first wave of closures in 1993 were in specific reaction to the newly promulgated air pollution control regulations. Smaller or older facilities did not have the financial strength to invest in the necessary air pollution control systems to meet the new standards. Tonnage processed grew through 1995, when energy from waste processed about 32 million tons of waste or about $14.5 \%$ of the municipal waste stream. Since 2006 total tons processed has hovered around 30 million tons annually. As of 2015 , this represents about $11.6 \%$ of total tons of waste generated.

Energy-from-waste plants are located mainly in the northeastern and southern regions of the United States. Northeastern states with their dense population centers and high landfill prices were early adopters of energy from waste technologies. In the south, Florida embraced the concept of energy from waste, looking to divert waste from landfills. Figure 6 shows the distribution of plants by region over time. What is most striking is that by 2016 , nearly two thirds of existing plants are located in the northeast

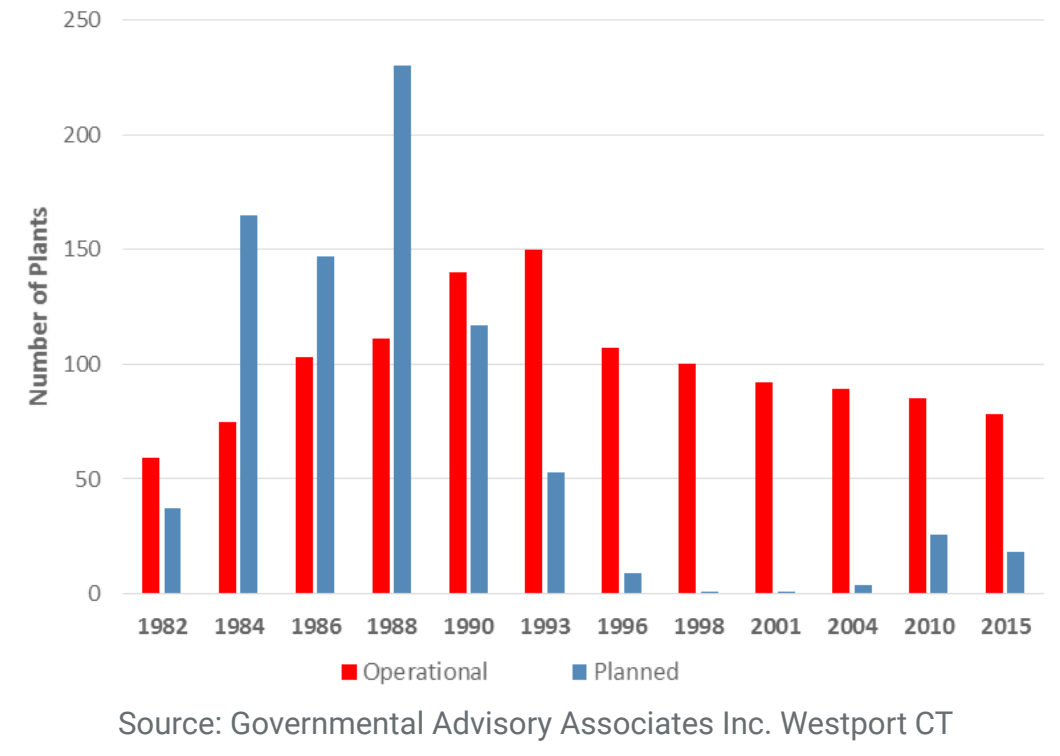

FIGURE 5: Number of operational and planned energy from waste plants by year. 
or the south. Due to the existence of less costly landfills with large capacities, the West and Midwest regions of the country have largely moved away from conventional energy-from-waste as a disposal alternative. Figures 7 and 8 reflect the challenging revenue environment confronted by energy from waste plants. Average tip fees charged by energy from waste plants, while increasing steadily to about $\$ 92.00$ per ton in 1994 (\$2016) began to decline after that point reaching their current average of about $\$ 61.00$ per ton. Similarly, electricity revenues have also declined from a high of 10.31 cents per kilowatt-hour in 1989 (\$2016) to about 6.60 cents per kilowatt-hour in 2016. Without any subsidies on electricity pricing under renewable portfolio standards or other renewable energy incentives, or any policies or regulations that might significantly drive up the cost of landfilling, energy from waste plants face an uncertain economic future in many parts of the United States. In addition, the high initial capital investment of $\$ 300,000$ per design ton and average operating costs of $\$ 99.00 /$ ton, inclusive of debt service, make economic feasibility problematic for any new plant that might be developed in most regions of the country. To the extent that there is downward pressure due to declining waste flows or declining prices, the facility has to compensate by raising tip fees. This is challenging in a competitive environment.

\subsection{Future Energy-from-Waste trends and tonnage}

The projections for conventional waste to energy plants in the near future are not favorable. No new plants are planned due to declining waste quantities, high capital costs, citizen opposition, and siting issues. Of the 78 operating plants, 16 may close within the next five years, representing about 4.3 million tons of annual throughput. Oppositely, three plants in Lee County, Florida, Pasco County, Florida, and Kent County Michigan are planning expansions, and other plants are anticipating increased throughput. The net loss of energy from waste capacity within the next five years is expected to be about 3.1 million tons.
Total waste processed annually from conventional waste to energy plants will total about 27 million tons, dropping to $10 \%$ of the municipal solid waste generated in the United States, rather than the $12.8 \%$ it is today.

While conventional energy-from-waste through combustion is declining in importance as a waste management alternative, gasification and anaerobic digestion plants appear to be the wave of the future. Gasification technology is viewed as a means to capture energy from waste without the toxic impacts of air emissions control and ash disposal that characterize waste combustion. Gasification facilities can be modular, operating at lower tonnage levels, to be scaled up to meet increased demand. Furthermore, gasification in theory achieves greater thermal efficiencies than combustion, resulting in higher energy production per input ton of waste than conventional waste to energy plants.

The drawback of waste gasification or anaerobic digestion is that it requires a high level of pre-sorting of waste to ensure that the resultant waste stream is of sufficient quality to be treated. Moving from bench scale to commercial operation of such plants has proved challenging. One of the first waste to bio-fuel plants to operate at commercial scale recently opened in Alberta Canada. The facility is designed to handle 100,000 metric tons annually of post recycled, pre-sorted waste. It has been producing methanol from the non-organic fraction of the waste that is sorted and sized to create a refuse derived fuel. Methanol production has been at lower levels than anticipated and there have been delays in moving to the production of ethanol, due to problems with the pre-sorting of the waste. Nevertheless, similar projects are being planned in Montreal Canada and Rotterdam in Holland. Other countries such as France and Japan have been operating gasification plants for several years.

Similarly, in conjunction with source separated organic collection programs that are being adopted in various states, local governments are looking to anaerobic diges-

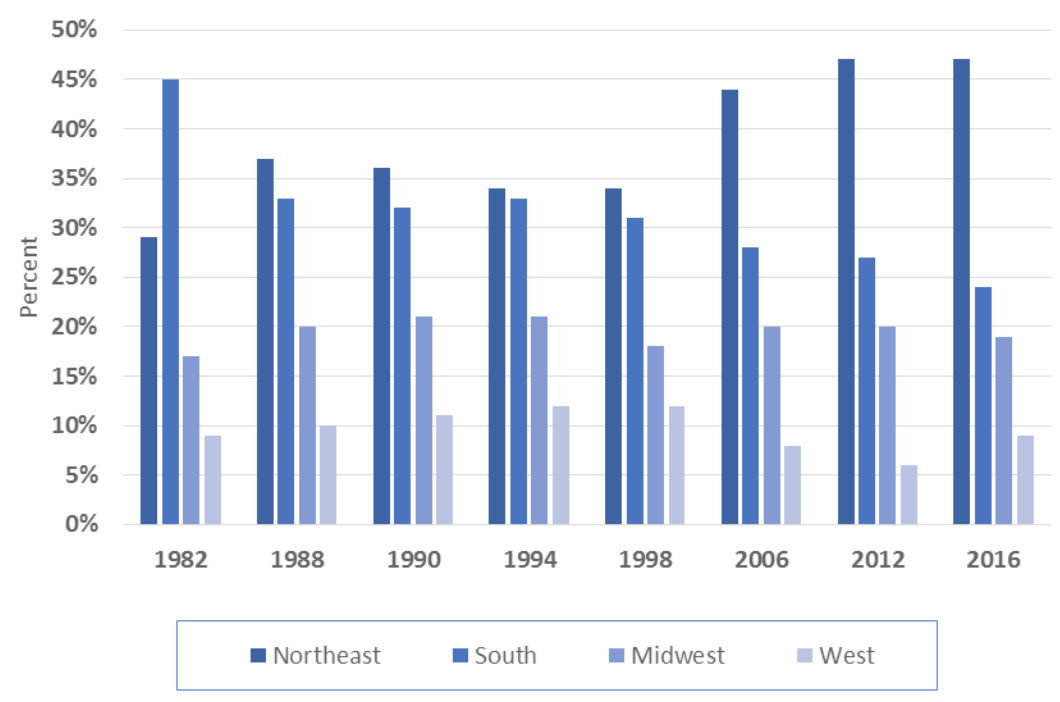

Source: Governmental Advisory Associates Inc. Westport CT

FIGURE 6: Distribution of energy from waste facilities by region over time. 


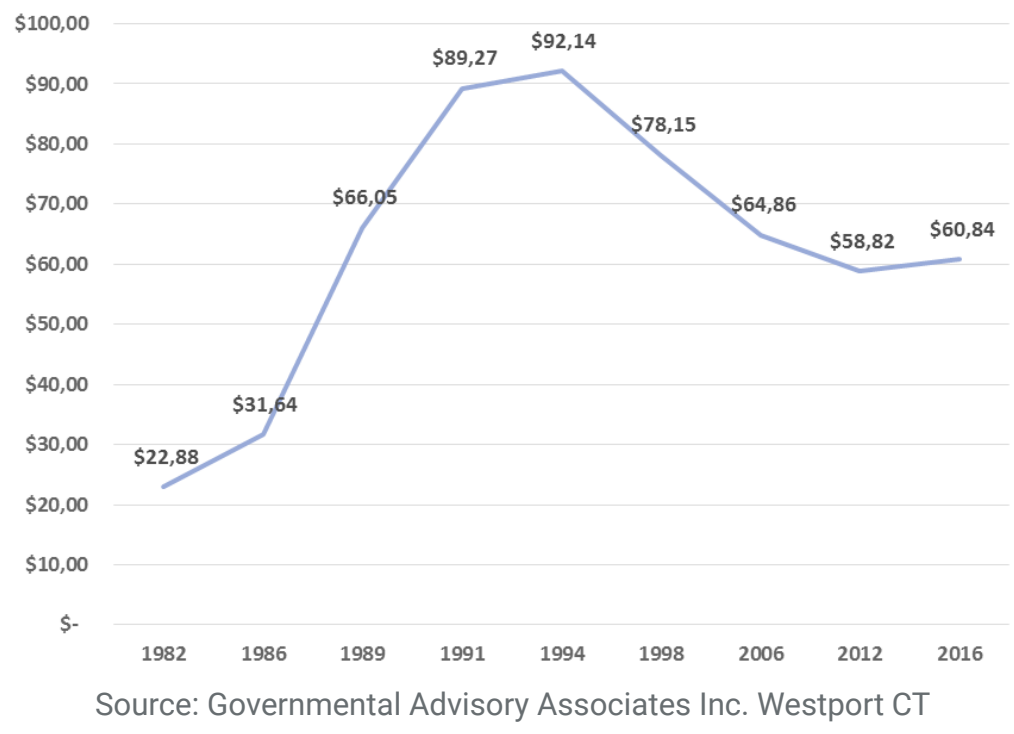

FIGURE 7: Average per ton tip fees charged by energy from waste facilities by year in 2016 dollars.

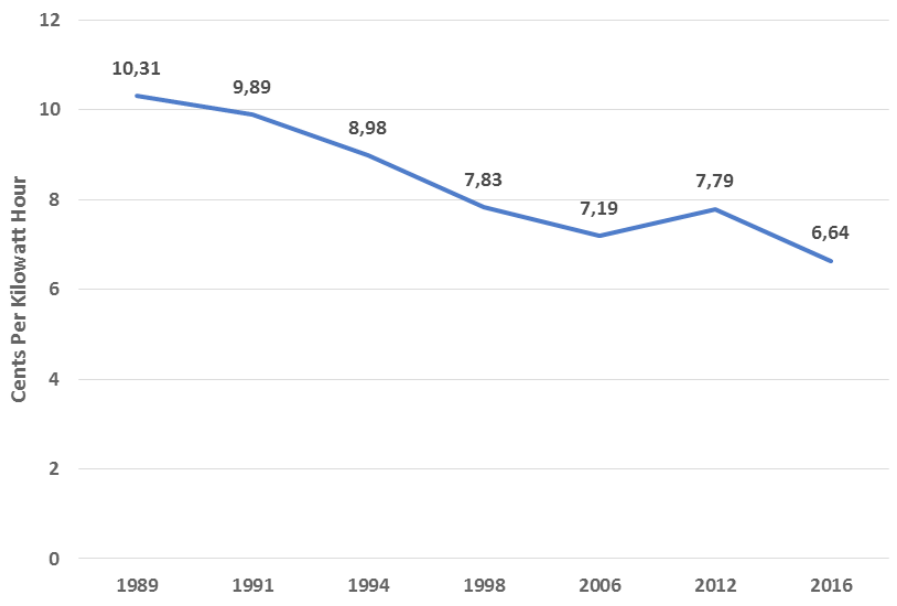

Source: Governmental Advisory Associates Inc. Westport CT

FIGURE 8: Average electricity rates obtained by energy from waste facilities in cents per kilowatt-hour by year in 2016 dollars.

tion to treat the organic waste stream. Most of these plants also require extensive pre-sorting. With the production of biogas and digestate, anaerobic digestion creates value from waste, without harmful emissions and a large amount of residual by-product, which requires landfilling. While such facilities are common in parts of Europe, there are only 15 plants in the U.S. solely dedicated to commercial and residential food. Improper waste sorting, difficulties in securing long term waste supply contracts and low energy revenues have made these plants difficult to finance and operate.

\section{CONCLUSIONS}

The United States is experiencing a paradigm shift in waste management. It is moving away from waste management as a disposal problem to waste management as a materials flow issue. The waste stream is being disaggregated into its component parts, i.e. organic, inorganic (recyclable, non-recyclable), residual, with various forms of treatment proposed for each stream. The overall goal is to decrease greenhouse gas emissions to the extent possible, to reduce waste and to reuse and recycle at maximum levels. Land disposal is no longer viewed as a waste disposal option, but the final resting place of low value residuals from various treatment and sorting processes. Under this paradigm, the bifurcation between recycling and energy from waste is blurring or disappears completely. Different levels of sorting will be required for each stream, whether such sorting occurs at the point of generation (residence or business) or at a centralized sorting and processing facility. Based on the sorting technology that is being developed, it may be more efficient to end curbside collection of separated streams. Separation and processing could occur at a fully automated plant, after which materials could be sent to an anaerobic digester, compost facility, gasification or other energy from waste plant, or directly to end markets.

Various factors cloud this future picture. There is no na- 
tional policy or systems of incentives to encourage state and localities to aggressively move to higher rates of re-use or recycling or waste conversion to energy. Policies and regulation vary by state and in some instances by locality. Electricity generated from combustion of solid waste does not qualify for renewable energy credits in many states. In other states, it qualifies for a substantially reduced subsidy. Waste gasification projects are given more beneficial treatment in most states, but levels of subsidy also vary by state. Certain states, such as California, Minnesota, Vermont, Massachusetts have implemented aggressive policies to meet landfill diversion and recycling goals, whereas other states have implemented less stringent policies.

In many areas of the United States, landfills remain the cheapest and most available disposal option. At disposal rates of \$25-\$35 per ton in areas of the Midwest or West, it is difficult for a local government to make the case to invest scarce public funds in alternative disposal options. In fact, due to the financial uncertainty that local governments face, some have dropped curbside recycling programs entirely and others have scaled back their program to cover only those materials with stable markets. It may be that sorting and waste treatment technology is currently outstripping economic feasibility in the United States. Optical sorters, sophisticated screens, computerized feedback loops, robotic sorters achieve efficiencies, but require high levels of throughput and maintenance. The result may be a high- quality end product with low value or quantity. Aggregating the various materials stream for processing at a centralized facility may achieve the necessary throughput to support a highly automated plant, but may result in a contaminated feedstock that degrades market price.

When one looks at waste management as a sustainable materials management strategy, there is a level of instability built into the approach. Waste continues to be generated at a given level, but materials markets are highly volatile. Revenues from the sale of materials or energy are not easily predicted, which makes budgeting within a local government difficult. While private companies often operate in the environment of commodity price swings, through future markets and other mechanisms, such behavior is not typical for a local government. Even if the entire waste management operation is privatized, once a private entity begins to lose money, there is no guarantee that the company will remain in business. Local government managers must take a conservative approach, since it ultimately their responsibility that waste be collected and disposed in a safe manner. In the near future it is states and localities that will serve as laboratories for future waste management strategies.

The data presented provides opportunities for continued research, which were beyond the scope of this paper. Are oil prices solid predictors of average recycling container revenues and if so, what kind of hedging strategies can localities and firms develop to protect themselves from market volatility. Similarly, do commodity prices drive recycling levels or is the implementation of recycling and other waste management alternatives driven by other factors beyond the materials market.

\section{REFERENCES}

Berenyi E. with Gould R.(1987). 1986-1987 Resource recovery yearbook: Directory and guide, Governmental Advisory Associates Inc., New York, NY.

Berenyi E. with Gould R.(1989). 1988-1989 Resource recovery yearbook: Directory and guide, Governmental Advisory Associates Inc., New York, NY.

Berenyi E. with Gould R.(1991). 1990-1991 Materials recovery and recycling yearbook. Governmental Advisory Associates Inc., New York, NY.

Berenyi E. with Gould R.(1992). 1991 Resource recovery yearbook. Governmental Advisory Associates Inc., New York, NY.

Berenyi E. with Gould R.(1993). 1992-1993 Materials recovery and recycling yearbook. Governmental Advisory Associates Inc., New York, NY.

Berenyi E. with Gould R.(1994). 1993-1994 Resource recovery yearbook, Governmental Advisory Associates Inc., New York, NY.

Berenyi E. (1996). The materials recycling and processing industry in the United States: 1995 Yearbook, atlas and directory, Governmental Advisory Associates Inc., New York, NY.

Berenyi E. (1998). The municipal waste combustion industry in the United States:1997-1998 Resource recovery yearbook, and directory, Governmental Advisory Associates Inc., New York, NY.

Berenyi E.(2002). Materials recycling and processing in the 2001-2002 yearbook and directory, Governmental Advisory Associates Inc., New York, NY.

Berenyi E.(2006). 2005-2006 Municipal waste combustion in the United States: Yearbook and directory, Governmental Advisory Associates Inc., New York, NY.

Berenyi E. (2008). Materials recycling and processing in the United States: Yearbook and directory, Governmental Advisory Associates Inc., New York, NY.

Berenyi E. (2013). 2012-2013 Municipal waste to energy in the United States: Yearbook and directory, Governmental Advisory Associates Inc., New York, NY.

Berenyi E. (2017). 2016-2017 Database of materials recovery and mixed waste processing facilities in the United States., Governmental Advisory Associates Inc., New York, NY.

Berenyi E. (2017) "Beneficial use of hard to recycle plastics: Current status and future projections. Draft paper. American Chemistry Council, Washington DC.

Brandes, William F. (2012). Waste-to-energy, state renewable portfolio standards (RPS) and the future of renewable energy, Proceedings of the 20th Annual North American Waste to Energy Conference NAWTEC 20, Portland Maine.

C\&A Carbone Inc. et.al, v. Town of Clarkstown, New York 511, US 383, 1994.

Capps, K. (2014). "What's behind the backlash to Houston's 'One Bin for All' program", Government Executive, July 21, 2014.

Cernansky, R. (2014). On the front lines of Recycling: Turning food waste into biogas. Yale School of Forestry and Environmental Studies, New Haven, Connecticut. YaleEnvironment360, e360yale. edu.

Columbia University Graduate School of Business Center for Government Studies (1983). 1982-1983 Resource Recovery Yearbook: Directory and Guide, Governmental Advisory Associates Inc., New York, NY.

Delmas, M., Tokat Y. (2003) Deregulation process, governance structures and efficiency: The U.S. electric utility sector. Research Paper 1790, Stanford Graduate School of Business, Palo Alto, California.

Kent, G. (2017) "Ethanol plant that converts old carpet, shoes to ethanol set to start production this summer" Edmonton Sun, April 19, 2017.

Marshall, C. (2017). The 2016 state of curbside report. The Recycling Partnership, Falls Church, Virginia.

Pytlar, T. (2016). Recycling markets impacts on solid waste management systems: Looking at the big picture", Federation of New York State Solid Waste Associations, 2016 Conference Proceedings, Bolton Landing, New York.

Rosengren, C. (2016) "Montgomery AL acquires closed mixed waste facility from Infinitus". Waste Dive, July 21, 2016.

Staub, C. (2017) "China mulls import action beyond national sword, Resource Recycling Newsletter, June 20, 2017. 
Sustainable Packaging Coalition (2016). 2015-2016 centralized study on availability of recycling. Prepared by RRS and Moore Recycling Associates, Inc., Charlottesville, Virginia.

United Haulers Assn., Inc. v. Oneida-Herkimer Solid Waste Management Authority, 550 U.S. 330 (2007).U.S.

United States Environmental Protection Agency, Landfill Methane Outreach Program. https://www.epa.gov/Imop/landfill-gas-energy-project-data-and-landfill-technical-data

United States Environmental Protection Agency, Office of Resource Conservation and Recovery (2016). Advancing sustainable materials management: Facts and figures 2014. https://www.epa.gov/smm/ advancing-sustainable-materials-management-facts-and-figures
United States Environmental Protection Agency. Sustainable materials management strategic plan; Fiscal year 2017-2022, October 2015.

Valkenburg, C., Walton, C.W., Thompson, B.L., Gerber, M.A. Jones, S.B., Stevens, D.V. (2008). Municipal solid waste (MSW) to liquid fuels synthesis, volume 1: Availability of feedstock and technology. Pacific Northwest National Laboratory, Richland Washington. PNNL18144.

Viny, S. Will the waste management industry morph into the resource management industry? (2015). Presentation at Solid Waste Association of North America, Waves of Change Conference, Clearwater, Florida, February 9, 2015. 